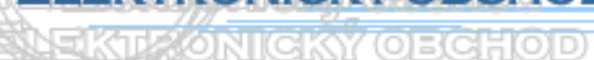

\title{
DIGITALIZACE: NOVÉ VÝZVY A NOVÉ MOŽNOSTI
}

\author{
Vladimír Bureš, Pavel Čech, Daniela Ponce ${ }^{1}$
}

\section{1. Úvod}

Digitální vysílání se pomalu stává realitou v mnoha evropských, ale i světových zemích. Po Velké Británii, která jako první zavedla digitální vysílání v roce 1998, Švédsku, které zahájilo digitální vysílání v roce 1999, nebo Německu, které jako první zrealizovalo přechod od analogového vysílání k digitálnímu tzv. ostrůvkovou metodou, se digitalizace v Evropě dostává také do států střední a východní Evropy. Př́ichod digitální televize přinesl nové př́ležitosti pro diváky, kteří tak mohou zintensivnit interakci s televizí např́íklad získáním dodatečných informací, volbou různých úhlů pohledu kamery, hraním her nebo př́stupem $\mathrm{k}$ internetu a emailům. Bohatší možnosti interaktivity přinášejí také př́ležitost využít interaktivní digitální televizi (iDTV) ke vzdělávání, tzn. k realizaci formy vzdělávání označované jako t-learning. Na této nové cestě je nutné překonat mnoho překážek z různých oblastí, např. kulturní, technologické, psychologicko-sociální či pedagogické.

Již brzo po prvních pokusech s televizním vysíláním na přelomu dvacátých a třicátých let minulého století byly rozpoznány možnosti využití televize jako média pro výuku. Digitalizace však vede ke kvalitativně nové situaci, jelikož iDTV má potenciál rozšířit možnosti vzdělávání v domácím prostředí. Důležitou roli přitom hrají klíčové prvky iDTV, mezi které patř́́:

- dostupnost - v současné době jsou v domácnostech Evropské unie (EU) televizní přijímače rozšířené více než osobní počítače,

- jednoduchost - relativně dlouhá historie používání televizních přijímačů umožnila zažití práce s tímto zařízením v podstatě u všech generací, od dětí až po seniory,

- interaktivnost - iDTV poskytuje možnost interakce jak na lokální úrovni (v rámci iAV aplikace), tak na globální úrovni (prostřednictvím zpětného kanálu).

Z pohledu vzdělávání je podstatné, že vysílaná obrazová data jsou hlavním výukovým materiálem (tzn. jedná se o tradiční pohled na vzdělávání za pomoci televize), která jsou však obohacena o aplikace poskytující dodatečné pedagogické funkce. $Z$ toho také vyplývá, že tlearning pracuje primárně $\mathrm{s}$ daty, která jsou vysílána, a sekundárně pak s daty, která jsou vyžádána uživatelem. Úroveň interaktivity tak záleží na divákovi a jemu dostupných technologiích. $Z$ pedagogického úhlu pohledu je také důležitá tzv. uvolněná interaktivita (lazy interactivity), která plyne $\mathrm{z}$ nižší úrovně soustředění a $\mathrm{z}$ jednoduchého způsobu interakce prostřednictvím dálkového ovládání televizního přijímače (bez klasické počítačové

\footnotetext{
${ }^{1}$ Ing. Vladimír Bureš, Ph.D., Ing. Pavel Čech, Ph.D., Mgr. Daniela Ponce, PhD., Katedra informačních technologií, Fakulta informatiky a managementu, Univerzita Hradec Králové, Česká republika, Rokitanského 62, 50011 Hradec Králové, email: vladimir.bures; pavel.cech; daniela.ponce@uhk.cz
} 
klávesnice). Vzdělávání pomocí iDTV tak směřuje k propojení dvou dosud často oddělovaných oblastí - vzdělávání a zábavě, k tzv. edutainmentu.

\section{Technologie digitální televize}

Z technologického úhlu pohledu je nutné zajistit, aby vedle hlavního vysílaného AV signálu byla vysílána také data obsahující vše nezbytné pro spuštění dané iAV aplikace. Obrázek 1 (převzatý z [9]) ukazuje způsob, kterým je iAV aplikace včleněna do vysílacího času diváka. Prostorem je šířen hlavní vysílaný signál obsahující např́íklad film (DVB stream). Tento signál je na vysílacím kanálu přijímán TV přijímačem, následně zpracován a zobrazen na televizní obrazovce. Kromě vysílacího kanálu je možné využít také zpětného kanálu, který však má jistá omezení, např́iklad, maximální objem dat přenášených zpětným kanálem je nesrovnatelně menší. Ani hlavní vysílací kanál však není bez omezení. Naprostá většina komunikační kapacity kanálu je zabrána vlastním AV signálem, tzn. fillmem, který je na televizní obrazovce zobrazen. Opět pouze nepatrná část tohoto kanálu může být využita pro přenos dat spojených s vytvořenou iAV aplikací. Prostor pro iAV aplikace je pak u jednotlivých provozovatelů různý. Situaci v Německu a ve Finsku naznačuje obrázek 2 (převzat z [10]). Tento princip iDTV, kladoucí požadavky na velikost iAV aplikací, je nutné brát $v$ potaz při jejich tvorbě.

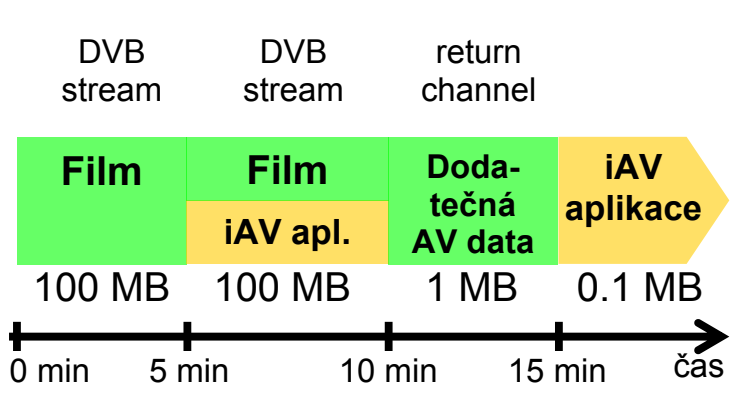

Obr. 1: Přenos dat k uživateli
Německo
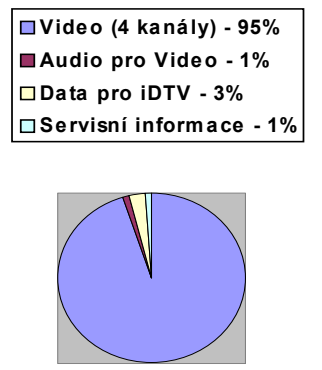

Obr. 2: Obsah hlavního vysílacího kanálu
Finsko
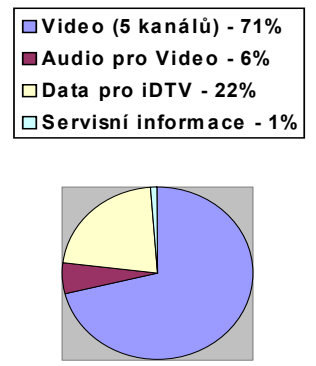

K využití př́ležitosti vzdělávat televizní diváky za pomoci iDTV je proto nutné prisstupovat systémově. Dříve než bude izolovaně řešen problém volby vhodného způsobu tvorby iAV aplikace, je nutné zvážit všechna omezení, která přicházejí v úvahu u celého procesu komunikace $\mathrm{v}$ rámci iDTV. Tento proces je zobrazen na obrázku 3 (převzat $\mathrm{z}$ [10]). Celý proces začíná na produkční straně vytvořením videa a vzdělávací iAV aplikace. Následně vysílací organizace (broadcaster) za pomoci multiplexeru tyto dva meziprodukty spojí a vysílá vybranou technologií (terestriálně, kabelově nebo satelitem) k uživateli. Díky možnosti využít zpětný kanál však proces komunikace nekončí u televizního diváka. Ten může v rámci globální interaktivity posílat data zpět vysílací organizaci. Při pohledu na popsaný proces je zrrejmé, že při využívání iDTV je nutné pracovat v rámci několika prostředí, jejichž produkty zajistí, že celý komunikační a vzdělávací proces bude kompletní. Těmito prostředími jsou:

- prostředí pro vysílání (broadcaster side),

- prostředí pro př́jem (home environment) - set top boxy apod.,

- prostředí pro vývoj iAV aplikací (iAV application development environment) a nástroj pro vývoj obsahu (content authoring tool),

- prostředí pro simulaci a testování (simulation and testing environment). 


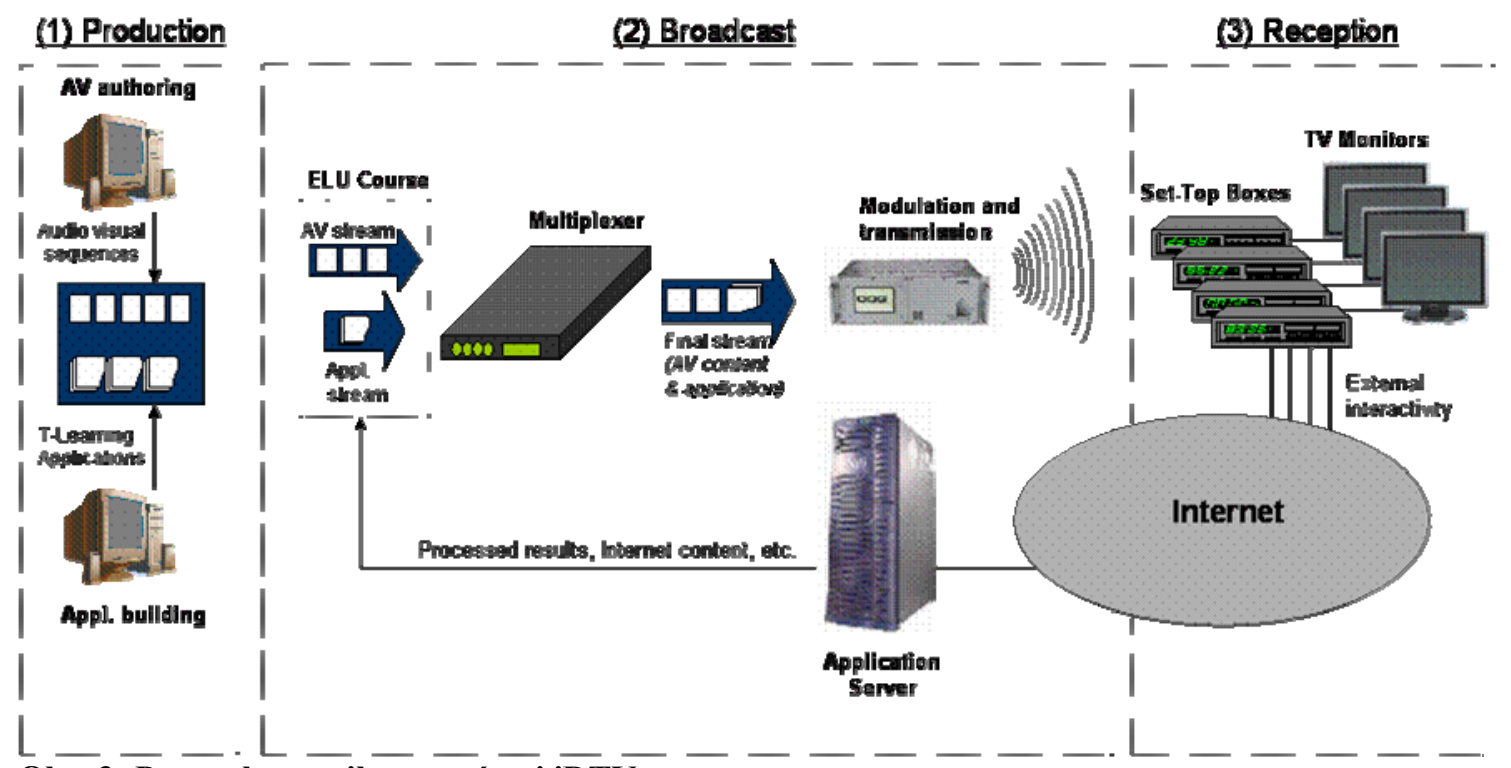

Obr. 3: Proces komunikace v rámci iDTV

\section{Prostředí pro vývoj iAV aplikací a nástroj pro vývoj obsahu}

Ačkoliv jednotlivá prostředí dohromady vytvářejí jeden komplexní systém, tzn. jsou vzájemně provázána a kladou na sebe různé podmínky a omezení, z pohledu tvorby vzdělávacích aplikací jsou nejdůležitější prostředí pro vývoj iAV aplikací (iAVAD prostředí), nástroj pro vývoj obsahu (CA nástroj) a prostředí pro simulaci a testování.

Mezi iAVAD prostředím a CA nástrojem existuje následující vztah. CA nástroj zpracovává data a metadata pro jednotlivé iAV aplikace. CA nástroj nevytváří samotnou iAV aplikaci, ale strukturuje obsah iAV aplikace. V některých prrípadech je možné rozšriřit CA nástroj na plnohodnotný systém pro správu obsahu (Content Management System). CA nástroj musí splňovat určité požadavky. Je např́iklad rozumné, aby výstup z CA nástroje byl kompatibilní s následně využívaným iAVAD prostředím, přičemž převod z CA nástroje do iAVAD prostředí by měl být automatizován nebo přinejmenším uživatelsky velmi přivětivý, nebo aby CA nástroj podporoval formáty typu SCORM.

iAVAD prostředí přeloží vytvořený strukturovaný učební materiál do iAV aplikace, která je spustitelná na set top boxu (STB). iAVAD prostředí má většinou uživatelsky př́ivětivé rozhraní, dokáže emulovat iAV aplikaci, díky čemuž je možné simulovat výsledný vzhled a chování iAV aplikace, je rozšíriitelné o další funkcionality apod. Mezi existující a relativně dostupná řešení patří např́íklad:

- Cardinal Systems,

- Icareus iTV Suite,

- JAME Author,

- MIT-xperts iDesigner,

- Alticast atd.

\subsection{Požadavky na iAVAD prostředí}

Při výběru konkrétního prostředí pro vývoj iAV aplikací je nutné sledovat, jakým způsobem naplňuje daný systém specifické požadavky budoucích uživatelů. Tyto požadavky je možné rozdělit následujícím způsobem (upraveno podle [9]): 
a) Funkcionální požadavky

- Generátor iAV aplikace

Hlavní funkcí prostředí by mělo být vytváření konečné iAV aplikace pro iDTV, která bude následně vysílána.

- Emulátor iAV aplikace

Prostředí by mělo poskytovat emulátor, pomocí něhož může uživatel testovat a simulovat budoucí produkt ve formě, v jaké bude zpracován pro platformu, na které běží set top box (platforma Multimedia Home Platform - MHP).

- Editor kódu

Výstupní kód by měl být editovatelný, aby s ním mohl uživatel snadněji pracovat a provádět v něm úpravy.

- Zálohování a obnova dat

iAV aplikace by měla být automaticky ukládána na lokální disk předtím než začne testování. To zajistí obnovu původních dat $\mathrm{v}$ případě, že emulace iAV aplikace způsobí jakékoliv problémy.

b) Nefunkcionální požadavky

- Strukturovaný vstupní formát dat ve formátu XML

Vstupní formát dat by měl být strukturovaný, nejlépe $\mathrm{v}$ jazyce XML, protože strukturovaná data jsou důležitá pro tvorbu MHP aplikace.

- Formát výstupu v MHP

Výstup by měl být $\mathrm{v}$ takovém formátu, aby mohl být vysílán pro iDTV, tzn. nad platformou MHP. Vhodné MHP-Java třídy jsou vytvářeny na základě strukturovaného XML vstupu.

- Optimalizace iAV aplikace

Velikost vytvořené aplikace by měla být optimalizována, aby zabírala co nejmenší část omezené kapacity vysílacího kanálu.

- Využití zpětného kanálu

Výsledná iAV aplikace musí být schopna využívat v př́ípadě potřeby zpětný kanál. Prezentovaný obsah iAV aplikace by měl mít možnost získávat nebo dodávat data přes zpětný kanál.

- Použitelnost prostředí

Uživatel by měl mít možnost pracovat $\mathrm{s}$ prostředím bez hlubších znalostí programování nebo po krátkém školení. Např́klad import strukturovaných XML dat nebo používání emulátoru by mělo být jednoduché a intuitivní.

- Cena

Cena prostředí musí být pro uživatele přijatelná. S cenou také souvisí např́iklad možnost nákupu základní verze prostř̌edí, která může být následně rozšiřřena.

- Servis

V průběhu používání vývojového prostředí je více než pravděpodobné, že uživatel narazí na problémy, s jejichž vyřešením bude potřebovat pomoc. Poskytovaný servis je tak více než nutný.

\subsection{Porovnání vybraných řešení produktů}

Pro ukázku vzájemného porovnání vybraných řešení jsme vybrali produkty iDesigner 1.1 a Cardinal Studio 4. Tyto dva produkty jsme porovnali na základě zkušebních verzí, které jsou dostupné na webových stránkách výrobců.

Prostředí - Ačkoliv oba produkty poskytují uživatelsky přívětivé prostředí, existují rozdíly ve způsobu vývoje iAV aplikace. iDesigner je více intuitivní, jednodušší a vcelku chytře řeší 
zajištění interaktivity. Vytvářený projekt je rozdělen do stránek, na které mohou být umístěny různé komponenty. Stránky tak představují obrazovky, mezi kterými se může uživatel pohybovat. Strukturu a chování vybraných stránek je možné spojit do šablony, která může být opakovaně používána. iDesigner umožňuje deklaraci globálních proměnných sloužících k dynamické změně stránek nebo obsahu stránek. Využití proměnných je možné rozšiŕit za pomoci jednoduchého programovacího jazyka s předdefinovanými funkcemi. Ty jsou využívány $\mathrm{k}$ modifikaci proměnných a jejich reakcí na události. Využívání proměnných a jednoduchých rutin umožňuje snadnou tvorbu základních iAV aplikací (např. her Sudoku, Pexeso či Logik).

Ve výše uvedeném smyslu je produkt Cardinal komplexnější. Naučit se s ním pracovat spotřebuje mnohem více času. Projekt je rozdělen na tzv. akty a vrstvy. Akty a vrstvy je možné zkombinovat podobně jako u iDesigneru stránky a šablony. Prostředí iDesigner ovšem nabízí jednoduší způsob přepínání mezi stránkami a šablonami vhodně uspořádanými do hierarchické stromové struktury oproti jednoduchému seznamu s akty a vrstvami u Cardinalu. Cardinal nenabízí možnost využívání proměnných nebo jednoduchých skriptů, tak jako je tomu u iDesigneru. Najdeme zde ovšem, pro účely zajištění interakce zcela dostačující, možnosti definování odpovídajícího chování jako reakcí na vybrané události. Užitečná funkcionalita Cardinalu je časová osa, která umožňuje přehledně uspořádat akty a vrstvy $\mathrm{v}$ čase. Nic podobného u konkurenčního iDesigneru nenajdeme.

Komponenty a možnosti rozšírení - Prostředí Cardinal nabízí více komponent než iDesigner. Obě prostředí umožňují využívat přídavné moduly a vytvořit si vlastní komponenty. Komponenty jsou napsány v Javě jako JavaBean objekty a lze je celkem snadno vytvořit podle př́kladů, které nabízejí oba nástroje. Zde je nutné upozornit, že použití interního programovacího jazyka (v př́ípadě iDesigneru) může znamenat roztříštění aplikační logiky do malých a špatně udržovatelných částí. Použití pluginů je systematičtější, a proto vhodnější pro složitější aplikace. V tomto směru je nástroj Cardinal sofistikovanější.

Obě prostředí umožňují práci s daty, ovšem chybí komplexnější příklad, který by možnosti práce $\mathrm{s}$ daty více osvětlil, a to nejen $\mathrm{v}$ daném prostředí, ale obecně pro použití v digitální televizi. Cardinal nabízí komponenty zajišt’ující zpětný kanál k určenému serveru. Produkt iDesigner resp. jeho výrobce (firma MIT-xperts) zajištuje zpětný kanál pomocí jiného nástroje. V této souvislosti lze upozornit na licenční podmínky iDesigneru, které umožňují nákup produktu ve třech verzích. Toto rozložení funkcionalit umožňuje uživateli využít pouze takový rozsah produktu, který potřebuje, a neplýtvat finančními zdroji na nákup kompletního balíku.

Př́klady, tutoriály a dokumentace - K oběma produktům výrobce dodává nápovědy, tutoriály a ukázkové prríklady. K prostředí iDesigner jsou dodávány praktičtější př́íklady ve formě her (viz výše) a iAV aplikací typu zpravodajského pořadu (předpověd' počasí, zprávy ze světa). U Cardinalu i iDesigneru existuje kromě běžných uživatelských příruček i technická příručka v podobě Java Doc a již zmíněných př́ikladů.

Shrnuti - Výhodou prostředí iDesigner jsou praktické př́klady, které mohou být snadno upraveny a využity pro různé projekty nebo pro potřeby studia. Jedná se především o jednoduché iAV aplikace, které lze vytvořit s použitím interního programovacího jazyka. Další výhodou produktu iDesigner je relativně jednodušší prostředí a ovládání, a tudíž kratší čas potřebný pro zaučení. Nevýhodou iDesigneru je proprietální programovací jazyk, přestože 
jeho použití může usnadnit vytváření interaktivity v aplikacích. Prostředí iDesigner nabízí méně komponent a pro využívání zpětného kanálu je třeba dokoupit další produkt.

Cardinal je komplexnější řešení vyžadující více času na zaučení. Výhodou je zahrnutí komponent pro práci se zpětným kanálem přímo do jednoho nástroje. Drobnou nevýhodou je složitější práce s komponentami při návrhu iAV aplikace. Svým rozsahem je Cardinal určen spíše profesionálním tvůrcům rozsáhlejších iAV aplikací.

\section{Pedagogický přístup}

iAV aplikace mohou mít různé cíle, např́klad zabavit, informovat či vzdělat. V rámci projektu ELU jsme se věnovali vzdělávacím iAV aplikacím, neboli t-learningovým kurzům. Každá vzdělávací aktivita by měla být založena na nějakém pedagogickém přistupu. Těchto př́stupů existuje relativně velké množství. Na základě podrobného výběru jsme zaměřili pozornost na využití pedagogického př́stupu R. Gagného (viz obrázek 4). Pedagogický př́stup R.Gagného se zakládá na způsobu zpracování informací, a proto byl vhodný pro námi vytvářené t-learningové kurzy (tematicky zaměřené na informačně-komunikační technologie). Pedagogický prŕstup R. Gagného lze charakterizovat jako posloupnost devíti různých aktivit (Gagné, 1985):

1. získat pozornost studujícího (gaining attention),

2. informovat studujícího o cíli učiva (informing the learner of the objective),

3. stimulovat připomenutí předchozích získaných schopností (stimulating recall of prerequisite learned capabilities),

4. představit podnět čili učivo (presenting the stimulus material),

5. zajistit vedení při učení (providing learning guidance),

6. požadovat výkon zahrnující odpověd’ neboli reakci (eliciting performance, involving response),

7. zajistit zpětnou vazbu týkající se správnosti výkonu (providing feedback about performance correctness),

8. vyhodnotit výkon (assessing the performance),

9. posílit zapamatování a přenos znalosti (enhancing retention and transfer of knowledge). 


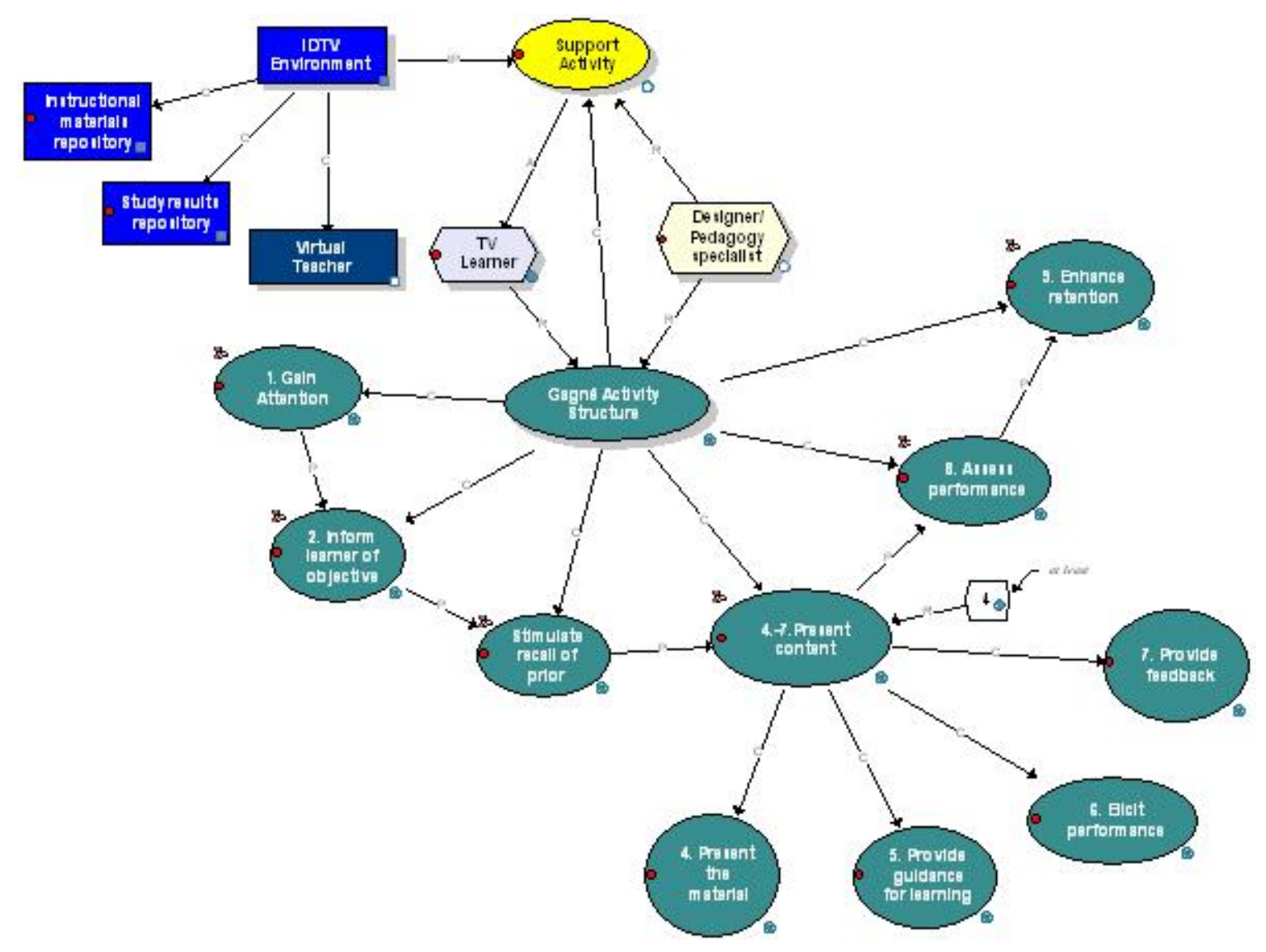

Obrázek 4: Gagného pedagogický přístup

\section{5. Životní cyklus t-learningového kurzu}

Složitost vytvoření t-learningového kurzu vyžaduje rozdělení celého procesu do několika etap. Podobně jako v klasickém životním cyklu informačního systému i zde jde o potřebu zdůraznění věcné stránky nad vlastní technickou realizací. I v případě tvorby tlearningového kurzu tedy můžeme aplikovat rozlišení jednotlivých etap podle otázek: „Co?“, „Jak?“a „„Č́m?“”.

V rámci otázky „CO?“ řešíme konceptuální stránku iAV aplikace, neboli, zajímá nás, co je nutné udělat pro dosažení stanoveného cíle učení. V konceptuálním návrhu řešíme otázky pedagogických cílů, souslednosti a návaznosti jednotlivých výukových činností, role účastníků kurzu, požadavky na podpůrné činnosti, prostředky a zdroje. U výukových kurzů by měl konceptuální návrh brát $\mathrm{v}$ úvahu vybraný pedagogický prrístup. Pedagogický príistup potom vystupuje jako určitá metaúroveň, kdy konkrétní průběh výuky realizovaný $\mathrm{v}$ tlearningovém kurzu představuje konkretizaci obecně formulovaných kroků vymezených daným pedagogickým přístupem. Vytvoření konceptuálního návrhu je úkolem především pro pedagoga. $Z$ technických schopností je třeba pouze zvládnout notaci specifikace, ve které je konceptuální návrh vytvořen. Ze své podstaty je konceptuální návrh možné využít jak pro tlearningovou, tak také pro e-learningovou formu kurzu. Odlišnost spočívá především v účelu a pedagogických cílech daného kurzu.

Etapa spadající pod otázku „JAK?“, označovaná jako implementační, vymezuje konkrétní výukový obsah jednotlivých činností stanovených ve fázi konceptuálního návrhu kurzu. Pro obsah je nutné zvolit vhodnou formu, ve které bude obsah prezentován. V této etapě vytváříme formální zápis pravidel a podmínek pro splnění dané části kurzu, resp. postup 
na následující část kurzu, př́ípadně i další akce či řídící struktury umožňující pohyb v daném kurzu. Na rozdíl od konceptuálního návrhu směřuje implementace ke konkrétní platformě a vybranému výukovému prostředí. Znalost dané platformy a výukového prostředí vyhrazuje vlastní proces implementace spíše pro technické pracovníky. V této fázi je hlavním úkolem pedagoga dodat obsah kurzu.

V implementační fázi je nutné počítat se specifiky a omezeními dané platformy. Pro tlearningové kurzy je platformou iDTV, kde existuje celá řada limitujících faktorů. $\mathrm{Z}$ technického hlediska je to především omezená interaktivita daná dálkovým ovladačem, zobrazovací a rozlišovací schopnost televizního přijímače, způsob vysílání a možnosti zpětné vazby. $Z$ pedagogického hlediska je potom základním limitujícím faktorem postoj učících se diváků $\mathrm{k}$ výuce prostřednictvím televizního přijímače. Dlouho utvářený postoj diváků $\mathrm{k}$ televizi jako $\mathrm{k}$ pasivní zábavě předurčuje tento způsob výuky především pro neformální účely.

Výukové prostředí pak dává odpověd’ na otázku ČíM bude daný kurz provozován. Tato poslední etapa představuje zprovoznění a vlastní provoz kurzu v konkrétním výukovém prostředí. Zprovoznění zahrnuje takové úkoly jako validace a publikování kurzu, zavedení uživatelů a přiřazení uživatelů do rolí v daném kurzu. Provoz kurzu představuje fázi jeho využívání, kdy je třeba kontrolovat především správnou funkčnost a také bezpečnost. Hlavní odpovědnost za činnosti ve třetí etapě má administrátor výukového prostředí. Všechny tři etapy jsou pochopitelně vzájemně provázané.

\section{Nástroje pro podporu vývoje t-learningové aplikace}

Pro vytváření iAV aplikací existuje celá řada univerzálních nástrojů, avšak žádný $\mathrm{z}$ těchto nástrojů není primárně určen pro tvorbu t-learningových aplikací. T-learningovou aplikaci je tak nutné vytvářet od úplných základů bez návaznosti na pedagogický př́istup a bez zohlednění specifických požadavků aplikací takového typu.

Jedním z výstupu projektu ELU je vývojové prostředí určené pro tvorbu tlearningových aplikací. Před tím, než bylo vývojové prostředí dokončeno, jsme pro simulaci životního cyklu t-learningového kurzu využili existující nástroje od třetích stran. Pro každou etapu životního cyklu t-learningového kurzu jsme využili jiný nástroj. Propojení mezi nástroji bylo zajištěno pomocí specifikace IMS LD, která definuje základní koncepty využitelné pro tvorbu výukového obsahu. Konkrétně jsme použili následující nástroje v dané etapě životního cyklu t-learningového kurzu:

1) Konceptuální návrh - MOT Plus

2) Implementace - Reload

3) Provoz - CopperCore

Všechny výše uvedené aplikace jsou určeny pro PC platformu. Výstupem prvních dvou etap je kurz, resp. výuková jednotka (Unit of Learning) úrovně A podle specifikace IMS LD (po první fázi konceptuálního modelování), resp. úrovně $\mathrm{B}$ a $\mathrm{C}$ (v druhé fázi modelování). Jednotlivé nástroje jsou podrobněji popsány v samostatných podkapitolách.

\subsection{MOT Plus}

MOT Plus byl vytvořen ve výzkumném centru LICEF Research centre Université du Quebec v rámci projektu MISA Method for engineering designing learning systems. Nástroj 
MOT Plus představuje jednoduchý objektově orientovaný grafický editor umožňující vytvářet modely nejrůznějších oblastí. MOT Plus podporuje notaci podle specifikace IMS LD, a proto je možné jej využít pro modelování výukového obsahu na konceptuální úrovni. Pomocí MOT Plus je možné poměrně snadno znázornit jednotlivé objekty tvořící výukový obsah včetně vzájemných vazeb. Při modelování je možné využívat víceúrovňové členění modelu podle zvolené hladiny rozpracování. MOT Plus obsahuje pravidla, podle kterých provádí jednoduchou validaci vazeb mezi určitými typy objektu. V nástroji MOT Plus je možné vytvořit model podle specifikace IMS LD úrovně A; pro dopracování dalších úrovní specifikace je vhodné využít jiných nástrojů.

V projektu ELU jsme nástroj MOT Plus použili pro vytvoření konceptuálního návrhu nejdřive na metaúrovni. Metaúroveň konceptuálního návrhu odráží zvolený pedagogický př́stup Gagného. Poté jsme daný konceptuální návrh rozšírili pro účely jednoho daného kurzu (zaměřeného na představení internetu). Devět základních kroků Gagného přístupu jsme rozpracovali do konkrétních aktivit. Rozpracovaný konceptuální návrh představoval pouze kostru, kde primárním účelem bylo znázornit obecný pedagogický př́istup ve vztahu ke konkrétním aktivitám, výukovým cílům a prostředkům. Výstup z tohoto nástroje je znázorněn na obrázku 4. Doplnění vlastního obsahu bylo plánováno na další fázi vývoje t-learningového kurzu. Přechod na další fázi byl zajištěn pomocí exportu z MOT Plus do balíčku podle IMS LD specifikace.

Smyslem této fáze bylo také ověření, že konceptuální návrh podle daného př́stupu by byl schopen namodelovat také pedagogický pracovník, který nemá hluboké technické poznatky o detailech IMS specifikace, ale dokáže pracovat s definovanými objekty a vztahy.

\subsection{RELOAD (Reusable E-Learning Object Authoring and Delivery)}

RELOAD představuje formulářový editor výukového obsahu vytvořeného podle IMS LD specifikace. Nástroj vznikl na universitě v Boltonu a Strathclyde. RELOAD je možné použít samostatně pro vytváření výukových kurzů v úrovni $\mathrm{A}, \mathrm{B}, \mathrm{C}$ podle IMS LD specifikace. RELOAD je též možné použít ve spojení s MOT Plus, kdy je konceptuální model importován do nástroje RELOAD pro doplnění metadat, vlastností a podmínek pro jednotlivé elementy.

V projektu ELU jsme zvolili druhý způsob. Nástroj RELOAD jsme použili zároveň také pro doplnění obsahu, který měl formu HTML a XML dokumentů. RELOAD nabízí relativně intuitivní rozhraní pro napojení jednotlivých činností na konkrétní dokumenty a pro vymezení dalších parametrů. V př́ípadě, že byl obsah tvořen testy nebo kvízovými otázkami, bylo nutné do daných dokumentů zakomponovat specifické značky. Tyto značky zajišt'ují propojení na metadata a vlastnosti IMS LD specifikace vyhodnocující odpovědi a počítající dosažené skóre. Pomocí vymezení sady podmínek bylo možné dosáhnout podmíněného zobrazování obsahu daného kurzu, resp. podmíněného přechodu na další aktivity. Znalost HTML, XML a některých detailů IMS LD specifikace omezuje dokončování kurzu pouze pro technicky zdatné odborníky.

\subsection{CopperCore Runtime Engine}

CopperCore slouží jako runtime prostředí pro spuštění kurzů vytvořených podle specifikace IMS LD. Poněkud složité ovládání limituje použití nástroje jen pro testovací účely. $K$ dispozici je také modul pro validaci vytvořených kurzů podle specifikace IMS LD v úrovni $(\mathrm{A}, \mathrm{B}, \mathrm{C})$. Nástroj je určen pro platformu PC. Pro účely projektu ELU jsme nástroj 
CopperCore využili k simulaci runtime prostředí, které by mělo být vytvořeno pro platformu iDTV. Dodržení IMS LD specifikace částečně odstiňuje předchozí etapy od konkrétní platformy. Stačí však, pokud i prostředí iDTV bude podporovat IMS LD specifikaci.

\section{Závěr}

iDTV přináší nové možnosti v mnoha oblastech. Patří mezi ně také vzdělávání. Efektivní využívání tohoto nového media je však podmíněno překonáním několika problémů. Mezi ně patři také výběr vhodného prostředí pro vývoj iAV aplikací, které umožní tvorbu iAV aplikací s požadovanými parametry. Na současném trhu je možné nalézt několik produktů. Při jejich výběru je nutné sledovat různá kritéria, mezi nimiž mají největší váhu cena, funkcionalita, poskytovaný servis nebo možnost úpravy prostředí dle individuálních potřeb uživatele (použití pluginů). Jako nejvhodnější se pro začínající tvůrce iAV aplikací ukázalo prostředí iDesigner, které je pro začátečníky přívětivější a rychlejší k naučení díky jednoduššímu prostředí a vytvořeným příkladům. Vytvářené iAV vzdělávací aplikace musí korespondovat $\mathrm{s}$ teoretickými pedagogickými přístupy. Jedním $\mathrm{z}$ vhodných přístupů je přístup R. Gagného založený na realizaci devíti kroků. Je však zřejmé, že při výběru pedagogických principů záleží na obsahovém zaměření iAV aplikace. Postup vytváření iAV vzdělávací aplikace by pak měl sledovat životní cyklus vytváření softwarových aplikací. K realizaci jednotlivých etap je možné využít různé nástroje (napřs. MOT plus, Reload nebo CopperCore).

\section{Použité informační zdroje}

[1] Cardinal Systems: Cardinal Studio Professional 4, [online], http://www.cardinal.fi/studio/studio.html, [1.11.2007]

[2] CopperCore Runtime Engine, [online], http://coppercore.sourceforge.net/, [1.12.2007]

[3] Gagne, R.: The Conditions of Learning, 4th ed., Holt, Rinehart \& Winston, New York, 1985

[4] Mikulecká, J.: Evaluace t-learningových lekcí, konference E-learning 2007, Hradec Králové, 2007

[5] MIT-xperts: iDesigner 1.1, [online], http://www.mit-xperts.com/products/, [1.12.2007]

[6] MOT Plus, [online], http://www.licef.teluq.uquebec.ca/eng/realisations/mot.htm, [1.12.2007]

[7] Olševičová, K., Rohrová, H.: Projekt ELU: pilotní lekce t-learningového kurzu, konference E-learning 2007, Hradec Králové, 2007

[8] RELOAD, [online], http://www.reload.ac.uk/, [1.12.2007]

[9] The ELU Consortium: Deliverable D2.1, ELU Technical Requirements and Guidelines for the iDTV Technologies, Paris, 2006

[10] The ELU Consortium: Deliverable D2.3, State of the Art - Learning using iDTV, Paris, 2006

\section{Grantová podpora}

Tento př́spěvek vznikl v rámci řešení mezinárodního projektu IST-4-027866 Enhanced Learning Unlimited (ELU). 